Article

\title{
The User and the Association: Neglecting Household Irrigation as Neglecting Household Well-Being in the Creation of Water Users' Associations in the Republic of Tajikistan
}

\author{
Katie MacDonald \\ Department of Geography, Syracuse University, Syracuse, NY 13210, USA; kmacdona@syr.edu
}

Received: 1 November 2018; Accepted: 5 March 2019; Published: 11 March 2019

check for updates

\begin{abstract}
Development initiatives often cite Water Users' Associations (WUAs) as fundamental to water governance reform or the broad process of decentralizing responsibilities for management, supply and delivery. But the label of "WUA" indicates little about those who take on these duties as association members, suggesting all who use water in pursuit of life or livelihood are eligible to participate and benefit through collective action. Grounded in the belief that participatory projects can equitably empower and distribute resources, the enthusiastic introduction of WUAs continues despite critique that anticipated outcomes are overstated. Since borders opened to neoliberal development institutions in the 1990s, WUAs have been created throughout post-Soviet Central Asia. Yet, there has been limited reflection on how associations' design and operation interact with physical or social structures to effect resource access across diverse groups. Drawing on fieldwork in Tajikistan, I demonstrate how WUAs reproduce exclusionary outcomes by requiring members to possess farmland in turn threatening rural food security. Held by a minority, farmland dedicated to commercial production stands in contrast to ubiquitous kitchen gardens, where crops sown for self-consumption form a buffer against hunger in the wake of labor migration and income inconsistency. Households' inability to become members undermines their claim to water and voice in decision-making, ultimately constraining access to irrigation and a robust harvest.
\end{abstract}

Keywords: water management; irrigation; kitchen gardens; participatory development; Water Users' Associations; Central Asia; Tajikistan

\section{Introduction}

Project plans and reports drafted over the last several decades by development institutions and donor agencies are peppered with references to Water Users' Associations (WUAs) as key components of rural water governance reform - their creation framed as an opportunity to transfer responsibility for local water management, supply and delivery from government bodies to those who directly engage with the resource as users. But beyond a shared requisite for water, the organizational label of "Water Users" Association" indicates very little about the qualities of would-be members, suggesting an inclusive design wherein all those who use water in pursuit of life or livelihood are eligible to participate and benefit through collective action. Grounded in dominant development theory and a belief in the ability of participatory, locally-based projects to empower without exception and equitably distribute resources, the enthusiastic introduction of WUAs has continued despite a rich body of literature arguing that these anticipated outcomes often fail to manifest [1-12]. The continued popularity of "participatory" natural resource management organizations signals that even with decades of critique, this area of study should not be seen as saturated but rather as warranting 
sustained attention to the variegated ways projects may perpetuate uneven power relations across the globe.

In Central Asia, WUA creation has taken place rapidly since the fall of the Soviet Union in 1991 as financially and administratively stressed governments opened their borders to neoliberal development institutions. Yet, there has been little critical reflection as to how WUA project design and operation have interacted with physical infrastructure or structures of power to affect resource access across social groups. Central Asia's location on the periphery of various constructed blocs-Eurasia and South Asia, the Islamic World and the West, the chaos of failed states and stability of democracy-has been mirrored in its treatment by academia as of peripheral concern. With respect to water governance, studies that do attend to the region focus on macro-level changes in surface-water availability or large-scale dam building in relation to the threat of interstate conflict or the boon of economic growth, with limited attention to the experiences of communities or household water users (See Nozilakhon Mukhamedova and Kai Wegerich (2014) for an exception to this trend [13]). This is not a call for regional studies within water governance literature, but rather recognition that insight may come from diverse locales and multiple scales of inquiry. In what follows, I examine the social relations produced when a mainstream strategy for contemporary water reform interacts with the physical and social structures of past systems of water governance, in this case a Soviet socialist one.

Drawing on evidence from the Central Asian Republic of Tajikistan, I demonstrate how WUAs created by development actors produce exclusion by limiting membership to those who possess farmland, leaving kitchen garden cultivators without a formal basis for engagement. In so doing, these institutions may inadvertently threaten rural food security. Dedicated to commercial production and held by a minority of rural households, farm plots stand in contrast to kitchen gardens, which, sown with diverse crops for self-consumption and held ubiquitously, act as buffers against hunger in the wake of labor migration and income inconsistency. The potential for kitchen gardens to continue in this function is, however, dependent on good environmental conditions and access to agricultural inputs-water, via surface level canals, being central among these. Restricting WUA membership to those with farmland shapes the local politics of water governance such that households who only cultivate kitchen gardens are not afforded a formal voice in decision-making and their claim to water is undermined. With policy informing practice, the rhetorical subordination of kitchen garden irrigation to that of farm plot irrigation has the potential to reduce household access to water, placing new constraints on rural food security and opportunities to improve family wellbeing - the antithesis of development actors' stated intent.

Connections between the receipt of adequate and timely irrigation water and rural households' access to nutritious food are clear, especially in Tajikistan's arid landscapes. Literature on water governance and WUAs in particular, does not, however, consistently integrate an analysis of how the politics of irrigation management affect household ability to secure sustenance, either through the cultivation of crops for self-consumption or through the sale of crops and the purchase of food. While analyses of water management institutions in abstract or divorced from their practical implications, do have value, they fail to fully account for the reverberations that shifts in water governance have through society. With an analysis of the relationship between household-level agriculture and WUA operation in Tajikistan, I demonstrate the importance of attending to the micro-politics of water governance in examinations of food security and in reverse, the importance of attending to issues of food security in understanding lived-experiences under different forms of water governance.

While directly in response to local conditions, international actors' decision to establish WUAs in Tajikistan cannot be understood in isolation from broader trends in development theory. After a discussion of research methods in section two, the third section of this paper traces the call for community-based organizations as an alternative to the state in managing natural resources, including water and how this call was translated by development actors into the construction of WUAs in agrarian communities. Turning to Tajikistan, the fourth section reviews recent political and economic 
changes that simultaneously increased the number of households reliant on kitchen gardens for adequate food access and degraded water delivery infrastructure and management capacity, such that the crop cultivation became more tenuous. After discussing WUAs' justification as responses to the new challenges in water management, I examine the treatment of kitchen garden cultivators in legal frameworks as well as how their inclusion is presented and practiced by different actors. The fifth section draws in literature on community-based natural resource management as well as empirical data to highlight the potential consequences of formally excluding kitchen garden cultivators from WUAs, with respect to community power relations and household access to water as well as rural food security, by extension. The sixth section provides a conclusion.

\section{Methods}

The information presented in the fourth and fifth sections of this article is based on fieldwork conducted in Tajikistan in 2017, contextualized by my work in the country over the last decade. In 2017, I focused on how water access for kitchen gardens was presented on paper, through an analysis of national water law and in practice, through interviews with WUA officials and rural residents. Fieldwork was concentrated in the southern province of Khatlon (See Figure 1), the nation's most productive agricultural region, famous for cotton, wheat, melon, tomatoes, cucumbers and other warm weather crops. Despite this abundance, the province also features high rates of food insecurity and was selected as a target site for the U.S. Government's Feed the Future (FtF) initiative, with projects organized by the United States Agency for International Development (USAID). USAID has been the driving force behind WUA creation in Tajikistan since the 1990s, supporting the creation of 60 WUAs in the last 13 years, most recently under the FtF.

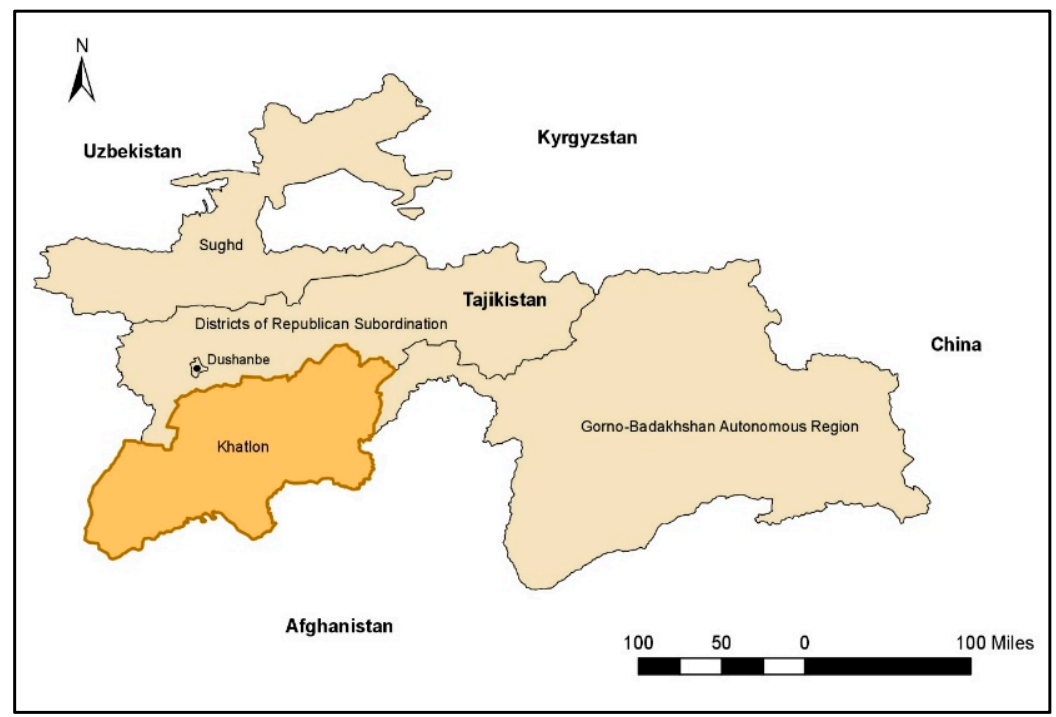

Figure 1. Provinces of Tajikistan.

There are four primary types of agricultural land in Khatlon: kooperativi istehsoli (agricultural cooperatives), which are similar in size (300 hectares or more) and structure to Soviet-era collective farms; dehqon (privately held) farms covering one or more hectares of land; zamini presidenti (presidential plots), parcels of land between 0.03 and 0.4 hectares that were distributed to families by presidential decree; and kitchen gardens, which are under one hectare in size (see Figure 2). Among these land types, dehqon farms, kitchen gardens and presidential plots are most prevalent. In this study, I focus on the relationship between kitchen gardens and WUAs, setting aside presidential plots and referencing dehqon plots only as a basis for comparison. Presidential plots are significantly less common than kitchen gardens and when they are held by families, are less frequently used to cultivate food that will be consumed by the household. Often far from irrigation canals or living quarters, 
these plots are instead sown with animal fodder that can grow with rainwater alone. As a result, WUA impacts on kitchen gardens, as opposed to presidential plots, will have a more direct bearing on household welfare.

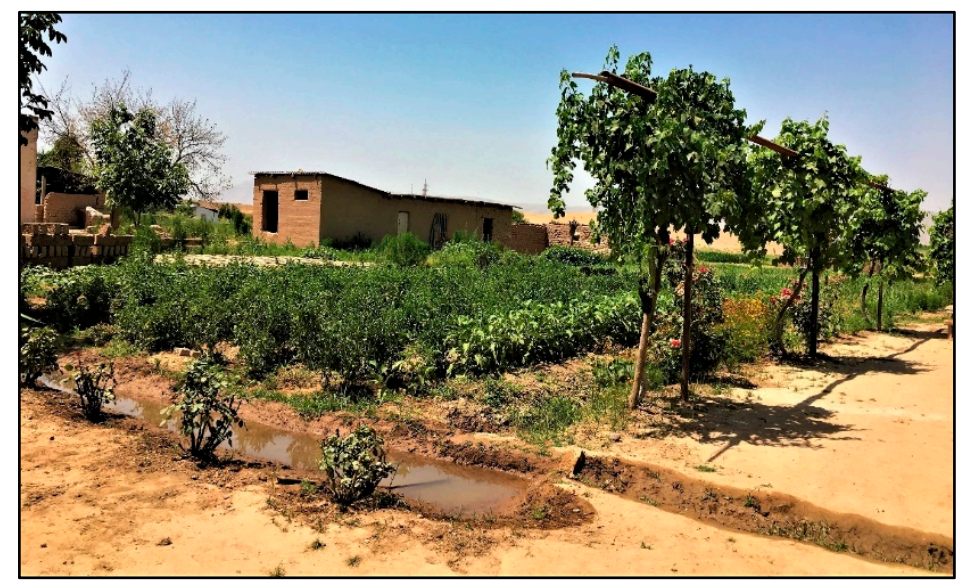

Figure 2. Kitchen garden in Nosiri Khusrav district, Tajikistan.

Within Khatlon, qualitative data were collected from the southwestern district of Nosiri Khusrav (see Figure 3), which is one of the 12 districts included as FtF 'Zones of Influence'. With no major industrial activity or urban centers, the population in Nosiri Khusrav is primarily dependent on agriculture for their livelihood. Groundwater (and the electricity needed to pump it) is out of reach for most families, either due to finances or geography and the cultivation of both farms and kitchen gardens is almost entirely reliant on surface-water irrigation. There are five WUAs in Nosiri Khusrav, all of which were created by USAID. With jurisdiction over hydrological territories stretching across three sub-districts, collectively, leaders of these WUAs count an estimated 6667 families within their area of service provision (see Table 1). Interviews were completed with water users in two villages within each of the five WUAs service areas, with the exception of WUA 5, in which case only one village was visited. To maintain respondent anonymity, village names and locations are not provided.

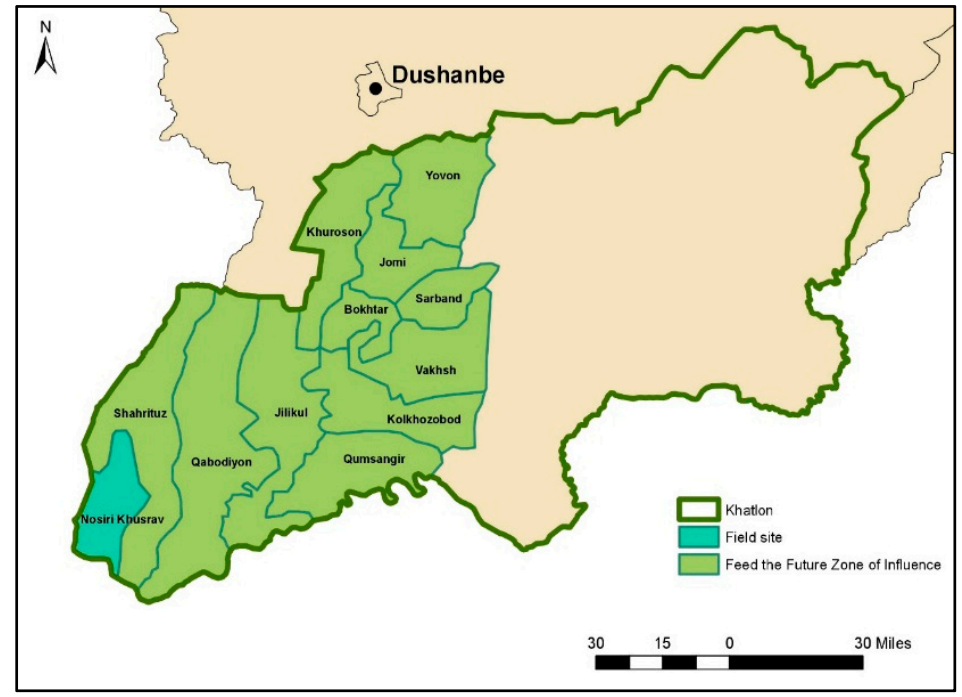

Figure 3. Districts of Khatlon Province, Tajikistan. 
Table 1. Water User Association (WUA) Coverage.

\begin{tabular}{ccccccccc}
\hline & & \multicolumn{1}{c}{} & \multicolumn{2}{c}{ Kitchen Gardens } & \multicolumn{2}{c}{ Dehqon Farms } \\
\hline WUA & Established & Villages & Households & Population & Number & Hectares & Number & Hectares \\
\hline 1 & 2013 & 6 & 759 & 3279 & 759 & 235 & 198 & 1971 \\
2 & 2014 & 3 & 756 & $3780^{*}$ & 756 & 370 & 89 & 486 \\
3 & 2013 & 4 & 1568 & 7841 & 1568 & 52 & 134 & 1132 \\
4 & 2013 & 12 & 2984 & 11,800 & 2984 & 1008 & 525 & 1500 \\
5 & 2014 & 5 & $600^{*}$ & $3000^{*}$ & $600^{*}$ & 120 & $550^{*}$ & 1300 \\
\hline
\end{tabular}

This information was collected from WUA leaders. One asterisk $\left(^{*}\right)$ indicates that WUA staff did not know or could not access this number and so provided an estimate. Land size represents total holding rather than cultivatable land.

In total, individuals from 40 households that do not possess a dehqon farm and seven individuals who do possess a dehqon farm were interviewed. Households and farmers draw irrigation water from shared surface water canals systems; tertiary canals are flanked by dehqon farms, followed by a village, followed by more farms and so on. Access to and control of resources often differs along gender lines. In seeking interviewees, I did not, however, target by gender; instead, speaking with whomever was most comfortable discussing kitchen garden cultivation. In Tajikistan, as in the rest of the world, space is gendered, with the bounds of public and private space traditionally accorded to men and women, respectively. As they are located within or near household compounds, women are associated with kitchen garden cultivation and indeed they are generally more involved with the kitchen garden than other agricultural plots. Men, however, may also be actively engaged in cultivation. Rather than rigid, the division of labor on kitchen gardens and within household units more broadly, is responsive to changing socio-economic conditions, including the age and health of family members, labor migration, war and conflict, and employment opportunities. Of the 40 households interviewed, I spoke with 18 women, three from female-headed households and 22 men, all of whom were from male-headed households. Among dehqon farmers, two were female and all were from male-headed households. I also conducted interviews with five individuals from or affiliated with USAID, two lawyers focused on consumer rights, land and water law, three representatives from local NGOs as well as three government employees in Tajikistan.

\section{Reframing the Role of Waters Users in Governance}

Access to water depends not only on its presence in a locale but also the physical infrastructure and social institutions that control this presence and by extension, shape its relations of power. Far from static, these relations evolve in response to changing global and local discourses and material conditions. The section that follows focuses on the transition in mainstream understandings of the function of a resource user in the process of governance from that of a reckless consumer to a relevant collaborator and the translation of this perspective into the development of participatory management models that in application, often failed to match their rhetorical framing as inclusive. Already the subject of much scholarly analysis, I review this history in order to locate WUAs within it, focusing on how these institutions embody an understanding of water users not only as collaborators but also as farmers. With this framing, those who depend on water for other uses, including kitchen garden cultivation, are made invisible in local water governance.

\subsection{Calling for User Participation}

Building on calls to give "voice to the voiceless", in the 1970s non-governmental and governmental organizations alike sought to reform the "expert" oriented development practices that dominated the sector by incorporating the knowledge and skills of "target" or "beneficiary" populations [14]. Associated with an extensive list of benefits, participatory development was argued to bring about more inclusive and transparent decision-making, facilitate creative problem solving, result in project designs better suited to local conditions and promote long-term investment in project institutions [15]. 
The absence of local participation in the research, planning and implementation of past development activities was seen as a key reason why anticipated outcomes had not materialized and zeal for overturning the norms of established theory grew throughout the 1980s and 1990s [14-16].

Participatory development arose from a sense of frustration with ineffectual development practices and marked "a protest against the existing orthodoxy" [17] (p. 7). But within a relatively brief period, it created its own orthodoxy [2,6,9]. In the late 1990s, the development community experienced a transition from what Irene Guijt and Meera Kaul Shah call a "participation boom" to a "participation imperative" as the term came to represent good or sustainable development and was closely associated with the language of democracy building $[14,17]$. The movement of participatory development from a radical intervention to a "best practice" is illustrated through its adoption by increasingly powerful neoliberal institutions. In 1996, the World Bank published their first Participation Sourcebook, admitting that reliance on an "external expert stance" had been (and some would argue still is) at the heart of their programs, yet they were now committed to a "participatory stance", in which "stakeholders influence and share control over development initiatives and the decisions and resources which affect them" [18] (p. xi).

The turn towards participatory development had significant implications for natural resource management, as conventional theories held that communities' interests inherently conflicted with rational resource use. The inability of state-centric, expert-led approaches to radically improve management prompted a re-examination of communities' interaction with their environment and research from the 1960s onwards demonstrated that "users have the potential and, under some conditions, the motives and means to act collectively" and self-regulate their resource use [19] (p. 92). Scholarship on common property management reinforced calls by indigenous populations to recognize the value of local resource governance, forming a coalition of actors that advocated for the transfer of control to communities. Increasingly the target of these groups' ire, in the 1980s the World Bank, among others, began promoting the rescaling and redistribution of resource governance responsibilities, such that state control was decentralized, and users took on a greater role in service and resource delivery [20]. A key element of structural adjustment policies, these transfers were argued to be more cost efficient, as "clients became involved in the production of their own services" [21] (p. 3). This rationale signals that while community-based resource management was intended to overturn established hegemonies, it did little to disrupt the neoliberal narratives that placed faith in the power of market-based incentives and privatized control to bring about effective governance. Decentralization has been critiqued as a rhetorical façade for business-as-usual, wherein external actors maintain primary control for project design and implementation under the banner of flexible, responsive approaches driven by local populations [21]. Regardless, the practice of devolving state control to communities is now common across thematic areas of intervention [10].

In the water sector, state-driven "hydraulic missions" that centered on technical fixes and the construction of large-scale infrastructure were critiqued for undermining poverty alleviation efforts, recognized as having negatively impacted surrounding ecosystems and decreased water quality or quantity for local communities [3,4,22]. In response, development actors sought to decentralize water governance through the creation of community-based water management organizations in rural and particularly agrarian, communities. Intended to increase water access for users, these organizations were based in the belief that local knowledge and the existence of communal understanding could be leveraged to create institutions that were responsive to users' needs, able to successfully implement agreed upon actions and resolve conflict as well as sustain practices over the long term [4,11]. As Karen Bakker writes, because "water is a flow resource whose use and health are most deeply impacted at the community level, protection of ecological and public health will only occur if communities are mobilized and enabled to govern their own resources" [23] (p. 441).

In 1976, enthusiasm for participatory, decentralized water resource management was put into practice in the Philippines as the Ford Foundation worked with the National Irrigation Authority to incorporate users into governance structures [24]. The transfer of small-scale canal operation 
and maintenance from government authorities to farmer associations, resulted in increased water access, equity of water supply, crop yields and household income according to follow-up studies [18]. Considered "the first and best documented nationwide program to build participation as a cornerstone of irrigation policy" [18] (p. 222), the reported success of this approach in the Philippines was quickly echoed by studies of similar state-to-farmer irrigation management transfers in Indonesia, Nepal and Sri Lanka, establishing faith in WUA creation as a replicable method by which poorly performing, centralized irrigation management systems could be reformed to strengthen rural livelihoods [25].

Specifically, WUAs were envisioned as a response to the failure of large canal projects to adequately attend to the flow of water to farmers' fields [26] (p. 79). Robert Hunt explains that in these projects, "direct bureaucratic responsibility ends at the outlet to the distributary canal ... Between the outlet and the farmer's field is a physical and social space for which neither the farmer nor the bureaucracy takes direct responsibility" [26] (p. 79). Development agencies and policymakers sought to clarify management procedures for this in-between space by increasing farmer involvement and fostering a sense of collective responsibility through WUA creation [26]. While local water management schemes have existed for centuries, WUAs differ from more traditional grassroots groups in that they are generally initiated by development organizations in collaboration with government authorities and incorporated into legal frameworks. Describing the guiding ethos behind WUAs, Hunt writes "if the farmers would only participate ... then the ditches would be constructed, the water would be allocated and most important of all, the maintenance would be done. Then water allocation would be optimized, food production would be maximized and the capital investment would be more efficient and effective" [26] (p. 79). As Hunt suggests, WUAs were also presented as an opportunity to cut the high-costs of centralized irrigation management, an attractive possibility for fiscally challenged governments and the international lending institutions that backed them. While irrigation was previously fully funded or subsidized by the state, with the introduction of WUAs, governments were encouraged by development actors to introduce or increase water user service fees. Collected by the WUA, these fees were expected to improve the cost efficiency of irrigation, covering operation, maintenance and repair. Confidence in this outcome was bolstered by evidence from Philippines which showed that by 1993, the cost of maintenance had decreased by 60 percent and personnel costs dropped by 44 percent [18].

In the last three decades, the popularity of WUAs as an intervention has accelerated, with rhetoric supporting WUA formation moving beyond pragmatic accounts of fiscal crises and the need to fill administrative gaps to include grander goals of improving food and livelihood security and empowering local communities-a veritable panacea for water governance and rural development alike. For example, in Sri Lanka, WUA activities were argued to have positive "flow on" effects for household income and food security [27]. Similarly, FtF publications have argued that WUAs play a central role in reducing hunger and malnutrition [28]. Going forward, academic analyses that directly respond to claims regarding the effects of these institutions on food security and rural livelihoods will be essential to understanding the politics of water governance in an era when concerns over "water wars" and "food crises" compete for attention in media headlines.

With participation framed as a form of empowerment, fostering women's engagement in water management, in particular, is promoted as a way to support "female emancipation" [5] (p. 598). Democratic decision-making has similarly become associated with WUAs, as project designs outline the election of group leaders, thematic sub-committees and meetings where all members have an equal opportunity to voice their thoughts [29]. Development actors envision that this experience with democratic procedures will then inspire civic engagement at a larger scale [27]. As the list of virtues associated with WUAs has grown, so too have the intended participants and beneficiaries, increasing from those described by Hunt, farm-level irrigators, to include agrarian households and communities more broadly. Yet, the extent to which WUAs' institutional designs reflect this shift in intention is questionable. 


\subsection{Designing for User Participation}

In their provocatively titled book Participation: The New Tyranny?, Bill Cooke and Uma Kothari pose the question "do group decisions lead to participatory decisions that reinforce the positions or the interests of the powerful?" [30] (p. 7). This query has been the subject of significant scrutiny in which scholars, extending the object of study to group activities as well as decisions, have critically argued that community-based resource management projects often result in elite capture or the exclusion of certain segments of society from resource control or access, namely women and poor households [2,4,5,7,12,31]. Nicholas Hildyard and colleagues aptly reflect the tenor of these critiques when they state that "far from unsettling oppressive relations, what passes for participation frequently serves to sustain and reinforce inequitable economic, political and social structures" [8] (p. 56). This point is stressed not to disparage all participatory approaches but rather to highlight that by the 2000s academic enthusiasm for this model was tempered by growing recognition that its capacity to empower across social groups and ensure equitable resource distribution was overstated, often masking underlying inequalities provoked or exacerbated by project design and operation.

Awareness of the potential for these projects to create or reinforce inequity among "beneficiary" populations was not, however, limited to academia. Cooke and Kothari note that their "conversations with practitioners ... were often characterized by mildly humorous cynicism, with which tales were told of participatory processes undertaken ritualistically, which had turned out to be manipulative or which had in fact harmed those who were supposed to be empowered" [30] (p. 1). Despite this recognition, the implementation and monitoring of participatory approaches has suffered from persistent inattention to communities' social dynamics as well as to the complexity of identity and livelihood strategies [5]. WUAs are no exception to this trend and while community consultations may nominally take place, association design is generally directed by development practitioners and is thus guided by perceptions of water use held by individuals external to the community in question. Across locales, scholars have observed that WUA designs are "donor induced" and implemented in a "top-down" manner [1,25,29,32].

WUA design inherently requires the formal demarcation of individuals in the community per their "relationship" with the organization, including who is and is not a member [33]. Though this process is often surprisingly opaque, over time "water user" has emerged as synonymous with an individual who cultivates their own irrigated farmland [26]. This meaning comes despite the reality that water sources are often simultaneously used for drinking, cleaning, watering animals, making bricks, milling and of course, household plot irrigation. Overlooking heterogeneity in target sites, notions of 'water user as farmer' are written into legal code and association rulings, which, dictating the practical terms of service, effectively curb the ability of WUAs to self-correct and account for diverse needs. In a comparative study of WUA legal frameworks in Colombia, India, Mexico, Nepal, the Philippines and Turkey, Salman Salman found that "most bylaws restrict membership of the WUA to the registered landowners in the hydraulic unit who are engaged on a full-time basis in farming" [34] (p. 8). A review of other scholarly publications and grey literature similarly indicate that WUA membership requirements most often limit eligibility to landowners or managers [32,35-39].

In this way, while WUAs were introduced as part of a broader movement to increase users' control over natural resources, control was in fact turned over to a particular user, farmers. This phenomenon is most clearly seen through membership eligibility stipulations, which are reflective of and contribute to a single-use mandate to serve farm-level irrigators, demonstrating limited consideration of the complexity of water-use landscapes in rural areas. As the livelihood strategies and resource uses of communities are in constant motion-responding to changing local and global conditions-the impacts of this false equivalency of water user and farmer require critical evaluation. It is with this in mind that I turn to Tajikistan, exploring the dual transformations in (1) rural life, as the kitchen garden became key to survival and (2) water management, as WUAs were introduced. While these are local changes, in drawing a connection between these two phenomena I seek to signal the need 
globally for greater consideration of how water management institutions interact with and respond to the dynamism of hydrologic and social landscapes.

\section{Rewriting Rural Water Governance in Tajikistan}

In 1924, the territory of what is today Tajikistan was incorporated into the Union of Soviet Socialist Republics (USSR) after which resource governance within its borders occurred according to the logic of the central Soviet government. During this time, modes of resources governance were left relatively unaffected by global shifts in development theory, but, following the dissolution of the USSR, this changed. On 9 September 1991, Tajikistan became independent and forces directing the management of natural resources began to shift as bi-lateral and multi-lateral agencies entered the country bringing promises of a better future through participatory development and decentralized resource control. WUAs were introduced in the late 1990s, soon after the end of a violent seven-year civil war that left the country, still reeling from the abrupt collapse of the Soviet Union, with deep socio-economic challenges. To ground the introduction of WUAs spatially and temporally, the following section explores the dynamics of irrigated agriculture and water management in the run up to and after Tajikistan's independence.

\subsection{Irrigated Agriculture in the Advent and Aftermath of Independence}

Forming a part of the Soviet Union's southern border, the Tajik Soviet Socialist Republic saw little industrialization and was principally organized around cotton cultivation [39]. To serve this objective, the USSR embarked on its own hydraulic mission in the 1920s, investing heavily in the construction of canals and pump stations across Central Asia, with existing irrigation systems seen as "tortuous" and the people unable to "properly care for their land" [40] (p. 460). After construction, irrigation system maintenance and operation were centralized. Primary control lay with the Ministry of Irrigation and Water Management whose policies were executed through administrative branches at the provincial level [37]. Provincial officials, in turn, worked with district irrigation offices to operate and maintain primary and secondary canals [37]. Flowing through secondary canals, water was then diverted to large collectivized farms, classified as sovkhoz (state-run) or kolkhoz (collectively-run), where it was managed by an "irrigation professional" who answered to the farm leader [41]. As they sent water to these farms, they also diverted it to villages, where it traveled through juibors (smaller scale earthen or cement canals) to kitchen gardens. Kitchen gardens have been grown in the area that is today Tajikistan for well over the last two centuries and their status as individual property was preserved during the Soviet period [42]. Ubiquitous among households in Nosiri Khusrav, respondents shared an understanding that kitchen garden cultivation during the Soviet Union was largely optional, rather than a necessity, as food prices were low, wages sufficient and shelves in stores were stocked with goods.

Reliance on kitchen gardens for food increased during the latter half of the Soviet period and into independence, as agricultural wages in Central Asia fell from 70 percent above the USSR average in 1958 to below the average by the end of the 1980s, and alternative income earning opportunities became scare [43]. After independence, a civil war ran from 1992 to 1997, plunging the economy into further turmoil. These changes went hand in hand with reduced access to food in markets, as prices rose, and the availability of some goods dropped. William Rowe, citing the World Food Program, writes that by $2000,88 \%$ of people in Tajikistan had changed their diet, eating less diverse foods and fewer total calories [42]. The consumption of basic staples similarly fell, including meat, cooking oil, milk and potatoes, with only wheat consumption increasing as bread replaced more expensive foodstuffs [42]. One respondent from Nosiri Khusrav lamented that "Before, when we worked on the kolkhoz, we got a salary and it would sustain us from month to month. At that time one person could provide for a family of ten people but now ten people cannot even provide for one person."

While more households were turning to their kitchen garden plots to provide regular access to fruits and vegetables, cultivation simultaneously became more difficult as access to water declined 
throughout the 1990s and into the 2000s. This was, in part, a result of budget shortfalls. From 1991 to 2002, funding for irrigation systems dropped from USD 72 million to just USD 6.5 million and only five to six percent of all needed investments in infrastructure repair and maintenance were made $[37,44]$. Violent conflict contributed to the neglect of irrigation systems and the loss of equipment needed for infrastructure repairs, with excavators and pumps sold-off or privatized during the upheaval. In Nosiri Khusrav, insufficient maintenance left canals filled with weeds, mud and stagnant water, increasing soil salinity in some areas. With good soil and sufficient water, kitchen gardens may be cultivated up to three times a year in this region. But under present conditions, many households can only crop once. A raisi mahalla (village leader) explained, "here my dear, we cultivate things with a lot of hope and prayer."

In the 1990s, the country's 354 kolkhoz farms and 348 sovkhoz farms were closed and land was redistributed to form over 10,000 dehqon farms (privatized farms) [45]. While these new farms have opened up new economic opportunities, they are held by a minority of rural households. A 2016 survey found that just 14 percent of households in Khatlon possessed a dehqon farm, yet 99 percent had a kitchen garden [46]. Kitchen garden cultivation is an important coping strategy for rural families in the wake of high food prices and low wages, yet the potential for these plots to continue to support household access to nutritious food is threatened by the condition of post-independence water delivery. This was highlighted by an elderly respondent in Nosiri Khusrav, who, standing in her kitchen garden of just under a hectare explained,

"Now it is really difficult for our family. If there were any benefit from our garden, I would say that [this plot could support us] but there is no water [flowing to the house]. I try to irrigate using a pump [in my yard] but it does not have much power, so it doesn't work well. Instead, I fill a large bucket with water and pour it into this apparatus," she said, pointing to a small backpack pesticide sprayer. "I spray the water by hand. People who work the land, their hearts burn when their plants do not receive water. What else can I do? I have to act to make sure the crops do not dry up."

We walked through her garden, stepping over unripe tomatoes that had dropped off the shriveled vines.

"Look here, everything has dried up. I could only salvage a little harvest ... When there is no food a person feels the weight of her family on her shoulders. If we had everything, I would not have grown old so fast. Look how old I have become because of the shortages we face. I am always thinking; how will we make food? We don't have potatoes, we don't have tomatoes..."

Gesturing at her daughter-in-law holding a baby in the doorway, her voice choked up,

"Look my grandson is crying, he has no clothes! If there was water I would sell [these crops] and we would have new clothes. My clothes and worn are threadbare. I am ashamed to wear them anymore. Just now I put this old party dress on when you came through the gate. If you don't believe me, I will show you."

Her situation is extreme but also far from unique. Above all, households in Norisi Khusrav reported that their water access is irregular. The availability of water early in the season allows households to sow seeds but as in the case above, later in growth cycle the intervals between water deliveries are often too great for the young plants to bare. A young man from another village recounted that until four years ago his family was able to successfully grow onions and potatoes for sale as well as other vegetables for their own consumption on their 0.10-hectare kitchen garden. "But now," he said "we can't. We get water for three or four days in a row, then our access is cut for nine or ten days." With summer temperature hovering around $110^{\circ} \mathrm{F}$, none of his crops can survive long without water. 
Seeming to wilt himself as he looked at his dried-up garden, Firuz explained that before they only went to the market for oil and rice, the rest of their food needs satisfied by their small plot. But now, his brother has migrated abroad in search of paying work to keep up with their bills at the local grocer.

\subsection{WUAs as an Intervention in "Chaos"}

In 1999, the World Bank authorized a loan of USD 6.5 million to rehabilitate irrigation infrastructure and create nine WUAs in Tajikistan, the first such associations to be organized in the country [47]. Following this precedent, other development agencies, including the Swiss Development Corporation, the Deutsche Gesellschaft für Internationale Zusammenarbeit, the Asian Development Bank, Helvetas International and USAID followed suit, creating more than 400 WUAs in less than two decades. In line with the impetus for community-based water management creation globally, these WUAs were envisioned as a means to (1) fill an administrative gap, (2) improve cost efficiency and (3) facilitate more responsive services by leveraging local knowledge and participation.

\subsubsection{Administrative Fix}

Land reform and the creation of thousands of new farms caused profound challenges for water delivery as the division of administrative duties did not undergo reconfiguration [37,48]. Changing little from the Soviet model, water governance occurred hierarchically after independence. Policy directives passed down from the Ministry to regional and then district offices, who were also responsible for managing primary and secondary canal systems. During the Soviet period, water would at this point be directed to tertiary canals and distributed to the kolkhoz or sovkhoz and villages by the farm's irrigation specialist. But with the breakup of collective farms, this position was eliminated, leaving dehqon farms and kitchen gardens without a clear service provider. Composed of water users jointly responsibility for infrastructure maintenance and operation, WUAs were intended to fill this "institutional vacuum" and ensure that water delivery is timely, adequate and equitable [41] (p. 238).

\subsubsection{Cost Efficiency}

Under the Soviet Union payment for irrigation water was resolved by collective farm leaders in cooperation with state authorities, meaning costs were not borne (directly) by households. But with the dissolution of collective farms and the creation of dehqon farms, payment practices required change. In 1996, a tariff on water supply was introduced, yet this failed to alleviate budget shortfalls [44]. Since this time, the cost of water services for users have increased by at least threefold; however, USAID asserts that the rate is still too low to fully fund the operation and maintenance of irrigation systems-a commitment Tajikistan made to the World Bank [49]. Irrigation authorities face difficulty collecting the fees from users, aggravating financial woes. The reported ability of WUAs in other contexts to act as cost efficient partners that can facilitate fee collection was a key rationale for the World Bank in introducing the institutions to Tajikistan [50].

\subsubsection{Participation and Coordination}

A central element of the World Bank's participatory approach to agricultural development in Tajikistan, WUA introduction is linked with fostering local engagement and its myriad benefits. A USAID implementing partner wrote that associations have "fostered community participation" and "serve as the face of the community to district government officials regarding water management issues" [51]. In connection, "good governance" is inspired and "community development" supported, as "water users working together along irrigation canals build and share critical knowledge on water-borne diseases, food preservation and children's nutrition [and] the associations also provide opportunities for women's participation and leadership" [52,53]. Theoretically translating to better water access and more robust harvests, WUA creation is also presented as an intervention in Tajikistan's persistent challenges with hunger and malnutrition, as indicated by its inclusion under the FtF program. 


\subsection{Household Incorporation}

Jenniver Sehring argues that most donors design WUAs in Tajikistan in a top-down process with "a rather unreflected, idealized notion of the 'village community"" [37] (p. 35). This is apparent in so far as WUA legal frameworks fail to account for the diversity of rural water users, advancing farmers as the water user. Of principle concern, is the deliniation of who WUAs should serve as laid out in the 2006 Law of the Republic of Tajikistan on WUAs. Section 2, Chapter 7, Article 43 of this law explains that WUAs "are created with the purpose to ... ensure fair, effective and timely distribution of water to dehqon farms" [54]. Suggesting that kitchen gardens were not considered during drafting, there is no mention of them in this clause or the law in its entirety. The absence of any reference to kitchen gardens would appear to leave WUAs' responsibility with regard to incorporating their cultivators as members open to interpretation. But local lawyers concluded that strictly speaking, this law prohibits households that only possess kitchen gardens from membership in the associations and denies them the right to request water for these plots from the WUA. As such, households that do not possess dehqon farmland-most rural households in Tajikistan-are afforded no formal voice in water management decision-making processes. Legal rulings, however, also exist outside of their physical manifestation as information that is processed, presented and put into practice by different actors.

\subsubsection{Government}

A lower-level government employee who coordinates WUA requests for water, confirmed that to her knowledge only farm managers can be association members but this understanding was not universal. Two higher level officials from agencies that work with WUAs, expressed confidence that the law allows households who only possess kitchen gardens to join associations as full members. One went on, however, to suggest that while they can be members, they should not be members as technically kitchen gardens should irrigate their plots with piped drinking water, not the water that flows through canals to dehqon farms. Yet, lacking adequate infrastructure for water delivery, piped drinking water does not generally flow to rural households and is more frequently provided through a spigot in a central village location, if provided at all. Recognizing the practical challenges in accessing drinking water, he went on to acknowledge that in practice, more than 90 percent of households rely on the flow of water down canals to irrigate their kitchen gardens. His statement on water sourcing, in combination with the discord among officials' regarding the law, further indicates that the question of kitchen gardens' legal access to adequate water has not been a priority.

\subsubsection{USAID}

An agricultural extension specialist for the USAID Tajikistan Agriculture and Water Activity (TAWA), articulated that the legal framework is not the only barrier to ensuring that WUAs effectively meet the irrigation needs of kitchen gardens. He explains, "when a representative of the association comes and asks a household to pay water service fees for their kitchen garden it is just 10 Tajikistani Somoni (TJS) or 20 TJS but for a dehqon farm, they must pay 2000 TJS or 20,000 TJS" because the service fee is determined by land size. His comments highlight that in comparison to households, WUAs have more financial incentive to ensure that dehqon farmers receive adequate water. Dehqon farmers who sign agreements with the WUA also pay membership fees, which as non-members, are not paid by households. A water specialist for TAWA reinforced this narrative but clarified that if the project timeline is extended, he hopes to support the formal incorporation of households into WUAs. Doing so, he believes, would have the dual benefit of providing the associations with more financial support and allowing households to formally call on WUA assistance for dispute resolution or infrastructure repair.

While project staff may influence implementation, they are acting within a framework established by USAID. An agricultural specialist for USAID Tajikistan indicated that in his tenure there had been little if any discussion of household irrigation needs at the agency and a presumption that dehqon farmers are the most important, if not the only, "water user" to be considered with regard to WUAs. 
This understanding is reflected in how USAID organizes its agricultural initiatives as under TAWA and preceding projects, the "water component" is separated from the "kitchen garden component." In a conversation with Doug Vermillion, an independent consultant who worked with USAID to design a water sector support strategy for Tajikistan, he lamented the agency's tendency to "fixate" on farmers and view the amount water used by kitchen gardens as inconsequential. But he argues that using the volume of water required as a measure of importance is misguided, for while kitchen gardens use a relatively small amount of water, its availability is directly tied to household wellbeing. An extension officer for TAWA similarly argued that the significance of kitchen gardens, not only for households but the economy in general, is often underestimated. Over the last decade, remittances have made up between half and one-third of Tajikistan's gross domestic product but he estimates that if the monetary value of kitchen garden cultivation was calculated it would exceed this amount.

"Why? Because kitchen gardens [if they are adequately irrigated and provide a good harvest] save households so much money ... They can get everything that is necessary for life by cultivating their land. They can buy food if they want but the amount of money sent by household labor migrants is generally not enough to buy quantities of produce that match those harvested from kitchen gardens."

\subsubsection{WUA Leadership}

Four out of five WUA leaders, felt that, in principle, they could legally incorporate kitchen garden irrigators as members. However, in practice, only one had taken steps to do so, signing agreements with households who have plots over 0.5 hectares in size (a move which, according to legal interpretations above, seems in conflict with the law). WUA leaders expressed that while they would like to incorporate households as members, they doubted their organizational capacity to do so. One chairman explained, "for example, we know that this guy, who has 0.4-hectares of kitchen garden land and he has problems getting water, sometimes he has water, sometimes he doesn't have water. But if he had a membership contract, we would know exactly when we should provide him with water according to exactly what hour." But he said to sign contracts and collect membership fees from the more than 1500 households in his territory is beyond the ability of the WUAs' three staff as they are already struggling to work effectively with dehqon farms. Several WUA chairmen noted that when their organizations were first established, they were told to only work with dehqon farmers, a directive that now seems shortsighted as other users, kitchen garden cultivators key among them, also draw water from the canals they are tasked with managing.

\subsubsection{Households}

Household responses as to whether or not they were a member of a WUA varied, though most said they did not think they were. I emphasize think as there was considerable uncertainty among households in answering this question, with many unsure as to what the WUA was or what constituted membership. Regardless of membership status, most households felt WUAs functioned primarily to serve dehqon farms, not kitchen gardens. One raisi mahalla said that although he only has a kitchen garden, he did sign a membership contract with the WUA. But now he wants out, saying, "at first I did not understand what the WUA was. Now I understand that there is no benefit for us." Another raisi mahalla located within a different associations' territory noted with frustration that "the WUA should pay more attention to the villagers. There are only five to six dehqon farms but there are more than 600 households (in his village). Now there are more conflicts. They give them [dehqon farmers] water first, before the households, so then they don't give us much water." As suggested by this raisi mahalla, an understanding of dehqon farmers as primary water users-a notion advanced through legal doctrine and reinforced by the inaction of government and development agencies-has material consequences. These consequences will be explored in the following section. 


\section{Undermining the Initiative: Consequences of Household Exclusion from WUAs}

Globally, scholars have documented that limitations on the ability of certain resource users to inform and participate in the activities of community-based management organizations have produced or aggravated uneven access to needed natural resources and in connection reinforced social and economic inequality. In Tajikistan, the full effects of household exclusion from WUAs are yet unclear, as all the WUAs in Nosiri Khusrav were constructed within the last six years and thus few have brought about dramatic changes in their service territories. However, this does not preclude the possibility that these organizations may bring hardship and division in the future. Households already face water shortages, the reasons for which are diverse but rather than ameliorate these challenges, I argue in this final section that a failure to include all resource users in WUAs can further reduce household access to irrigation, as they are denied an opportunity to formally engage in decision-making processes and deepen community division. Such outcomes, if they come to pass, are antithetical to the objectives of WUA creation-undermining the notion that rural water management will be transformed to increase the equitable supply of water, the size of harvests and food availability.

\subsection{Coming Together and Creating Division}

Fundamentally, the creation of formalized divisions within a resource user community along the lines of organizational membership sets the stage for dispossession, as the claims of one group, "members," to the resource are valorized over other that of another group, "non-members." As discussed earlier, within a WUA service area, this division is generally determined by a requirement that members be farm managers. Viewing this membership stipulation in connection with Edella Schlager and Elinor Ostrom's five categories of natural resource rights-access, withdrawal, management, exclusion and alienation—brings its consequences into sharper focus [55]. Even if their access water is initially preserved, as non-members, households without farmland are vulnerable to the loss of future access because they lack a formal right to (1) exclusion or the ability to dictate who can access the resource, (2) alienation or the ability to sell or lease access rights and (3) management, which includes the ability to define patterns of withdrawal and [55] (p. 10). As kitchen gardens tend to feature greater crop diversity than farm plots, the inability of their cultivators to formally articulate and protect their needs during the scheduling of water withdrawals elevates concerns that water will not be received at the right time or in the right quantity.

Empirically affirming this dynamic, Leila Harris writes that when water user groups were formed in southeastern Turkey, water delivery was scheduled to align with the needs of members-farmers, who primarily grew cotton [56]. Meanwhile the irrigation requirements of household vegetable plots went unaccounted for as the women who tended these plots were non-members [56]. In this way, group design threatened households' food security. But, Harris notes, "it is not only that women are excluded from user group activities but that women, the landless and other segments of the population are codified as 'different' or more or less 'appropriate' as farmers with respect to ongoing negotiations of water user groups" [56] (p. 95). Restricting membership to farmers legitimates and advances an understanding that their water use and in connection, their cultivation, is of principle importance in the community. This practice fortifies notions that "productive" water uses, being those that generate income, such as commercial agriculture and industry, take precedence over "domestic" uses of water, conceived of as household consumption, cleaning, food preparation and hygiene but may also include kitchen gardening [57].

"Domestic" uses of water are traditionally carried out by women. As such, when the design of a water management organization, like a WUA, favors or focuses exclusively on "productive" uses of water, women's claims to water are repudiated and the value of their labor in the domestic sphere denigrated relative to that of men engaged in farm-level cultivation. Moreover, conceptions of irrigation management as a masculine activity are reinforced, obscuring women's role in this process. Analyzing WUA design goes some way in supporting Margreet Zwarteveen's call to move beyond the identification of inclusion or exclusion and "to explain the 'absence' or 'invisibility' of women from 
irrigation and politics" by considering the ways in which diverse, culturally and historically specific structures often lead to a connotation and configuration of irrigation as male-dominated [58] (p. 127).

While the exclusion of kitchen garden cultivators from WUAs does have gendered implications, at its most basic level, those who are ineligible for membership are households without farmland. When a household does not possess farmland, male family members frequently assist or act as the primary cultivator of garden plots, meaning, membership restrictions can divide a community not only along the lines of gender but also land tenure. While acknowledging the importance of gender relations, Andrea Cornwall warns that an examination of this area alone may generate essentializing, simplistic conclusions of "woman-as-victim" and "man-as-problem" [6] (p. 1326). Harris signals the importance of attending to both gender and land tenure in her analysis of water user groups in Turkey [56]. As members were required to have a land holding of four or more hectares and few women have land titles, they were underrepresented in user groups [56]. Group members were thus overwhelmingly men; but also landed and therein elite, relatively speaking. With high rates of landlessness in the area, Harris estimates that "70 percent of the adult population is barred from meaningful participation" in the group, despite their dependence on water it manages [56] (p. 192). A policy whereby only farm managers can become members reinforces their elite status in the community, leaving households that only possess a kitchen garden marginalized with regard to access to water and importantly, information.

If a significant portion of the community is precluded from formally engaging in organization activities, access to information becomes uneven, as those with farmland are, in theory, provided exclusive opportunities to learn about the technical and administrative procedures governing irrigation via their membership. In addition to disadvantaging non-members, an uneven distribution of information can threaten WUAs' ability to function effectively, as they require users' respect of agreed-upon practices for water withdrawal, fee payment and maintenance regardless of membership. Goldin highlights how inequity in information can subvert trust - the foundation of community-based natural resource management [59]. She writes:

Knowledge is a pillar for participation and poor people are unable to take control over their environment and to participate in decisions to improve the quality of their lives without knowledge about the resources on which they depend. The absence of knowledge, the unequal power relationships between water users and the inhibition of agency, frustrate the process of participation because the production of trust is inhibited and feelings of shame, that aggravate issues of social exclusion and negate social agency, are activated. [59] (p. 197)

Goldin recounts how one water user she spoke with in South Africa was unfamiliar with the terminology used in a group discussion but because he was paralyzed by the fear of shame or ridicule, he remained silent and was unable to substantively engage [59]. The connection between unequal access to information, shame and silence operates in a "vicious cycle" [59] (p. 204), that extends beyond the sphere of the organization and resource use to strengthen the hold of elite groups on information and perpetuate the exclusion of poor or marginalized populations in society more broadly. Quoted by Goldin, the water user explained,

"shame is about being hungry. I know shame, when I am inside the committee I will just say yes until I learn and they will not know how poor or ignorant I am. It is a terrible thing when you feel hollow inside. Hunger can make you feel this and not knowing anything can make you feel this." [59] (p. 208)

His quote highlights the irony that an organization established to increase water access and crop yields can in fact produce hunger-both physically, as seen in the proceeding section when access to water is curtailed and intellectually, when access to information is unevenly distributed. 


\section{2. "Water for [the] Life [of the Farmer]"}

In 2005, Tajikistan's government launched the International Decade "Water for Life" in collaboration with the United Nations to attract support for water governance reform globally and within their own borders. While it was intended to embody the ethos of national water development, when the phrase "water for life" is viewed in the context of WUA membership policies, it begs a correction. For households living within the jurisdiction of a WUA, the phrase would more accurately read "water for the life of farmers" - in both a literal and rhetorical sense. Currently, the exclusionary nature of WUA membership does not appear to be the locus of significant challenges in water access for households. However, I question the extent to which this outcome is temporary and subject to change as both the intensity of WUA involvement in water management and overall climatic aridity increases with time. Households already express a sense that farm plots and the individuals who possess them, are treated as superior with regard to water access, a trend that WUA membership policies are only likely to exacerbate.

\subsection{1. "They Do Not Give Any Water to the Village"}

The control of water management organizations by commercial farmers often means irrigation schedules are designed for cash crops-patterns of water delivery that are unlikely to satisfy the needs of the diverse crop cultivation that characterizes kitchen garden agriculture. In Nosiri Khusrav, respondents argued that this has already come to pass, as the irrigation of cotton and rice is privileged to the detriment of kitchen garden cultivation. As WUAs become more established in the district, this is unlikely to change.

In Tajikistan, the irrigation season is set to begin around mid-March for both households and dehqon farms. From this point, water is expected to flow through canals until November, after which they are closed again for winter. While frigid temperatures preclude most large-scale cultivation, household need for water to cultivate winter crops continues. No water in canals from November to March brings further stress in villages without piped drinking water, as it means households lack water for drinking, cleaning and their animals. Most respondents reported adequate water access for their kitchen garden and household needs in early spring and late fall but that between these two periods challenges abounded. Households consistently described shortages during May, June, July, August and into September, months crucial for crop growth and when temperatures are at their peak. While the specific causes of water shortages in different vary and may have a great deal to do with the condition of infrastructure, because of the seasonality of their reduced water access, many respondents attributed this phenomenon to the water use practices of those with whom they share the canal-dehqon farms.

As noted before, dehqon farms in Nosiri Khusrav principally grow cotton. Planted in March, the most critical period for irrigating cotton falls between May and August. Summer "is really tough for us ... because the cotton is flowering. If we don't give them water on time, they fall off and the whole harvest will just fall away," a farmer explained. When asked if households ever ask him, as a dehqon farmer, to release water to the village during this period, he replied

"Yes, this has happened a lot... After talking with them [the WUA] ... we say alright, one week, one time it is necessary for us to give water to the community ... In the night, poor people [villagers], we give them water ... but just two or three people use up the water and the rest just have to stay [without]. They fight and mobilize to try get water. I think we don't give them enough ... The poor households, those people with kitchen gardens, it is really difficult for them. But giving water to dehqon farms is ultimately more important because we have to irrigate a lot of hectares of land and we sign contracts and give cotton and other products."

An understanding that during the summer, irrigation water is used first and foremost for farm-level cultivation was echoed by households throughout Nosiri Khusrav. "The deqhon farmers take water and they do not give water to the village," one woman said, "the people [in the village] 
pay the tax [water service fee] but we don't have [enough] water ... when our crops dry up, we have to buy food. Sometimes we work in Russia to earn money, no one works for the government or gets a salary. We do work for the dehqon farmers but we just get cotton stalks [to burn as fuel] and for picking cotton we get just 0.4 TJS per kilo (approximately 0.05 USD)." Her neighbor confirmed this practice, expressing similar frustration that households contribute both monetarily and in labor to the upkeep of the irrigation system yet see less benefit. "The people do not have as much rights as them," she explained, "during the day, four dehqon farmers [from her village] take the water, they don't give us any. Then when it's time to clean the joibor, only one person from the dehqon farm comes. But the villagers, they all come." Exasperated with inequity in water division, another woman bemoaned that, "farms and households should have an equal right to water. They all have to survive." As dehqon farm managers are currently the only rural residents eligible for membership in WUAs, a hierarchy of water use that favors farm-level cotton cultivation over household cultivation is unlikely to change. Rather, as WUAs become more active and gain better technical control of the process of water delivery through the repair of canal systems and water gates, the position of kitchen garden irrigation as of secondary consideration is likely to become ingrained in association practice, translating to inferior water access.

Differentiated temporally throughout the year, farm and household access to water also differs across the span of $24 \mathrm{~h}$. Throughout Nosiri Khusrav, water is usually provided to farms during the day, then in theory, is sent down village canals at night. One woman relayed that, "until six o'clock the dehqons take water and after six o'clock the people [receive water] but how can women go out at six in the evening and get water?" With male out-migration pervasive in rural areas and an overall feminization of agriculture in Tajikistan, gendered barriers to water access warrant significant consideration [60]. The chairman of the WUA that covers her village said that the timing of water distribution does not present any difficulties for households. "We watch over them and if their husbands are not there we give them water in the daytime. If they are a laborer we also give it to them in the day, if they are a boss with workers we give it to them in the night," he explained. The logistical potential of such distribution aside, a farmer in his territory I met later in the day noted that he had been up all night irrigating his plot, as he preferred to distribute water when it was cooler to minimize evaporation. This leaves doubt as to whether households' access to water is protected even during their allotted time.

\subsection{2. "The Voices of the Household Mean Nothing"}

"In the Soviet Union, there was one rais (leader), now they are everywhere!" explained one woman with a laugh. Her statement references the shift that occurred with land reform, as the area surrounding her village transitioned from being managed by one man, the head of a large collective farm, to being managed by hundreds of dehqon farmers. Farm leaders, particularly those cultivating cotton, commanded respect during the Soviet period and reverence for the position has carried on post-independence. Yet, as the position has changed from being held by one individual across many villages to being held by many individuals within each village, ingrained notions of farm leaders' privileged social status have created challenges for water management. An employee of the Land Reclamation and Irrigation Authority explained that she often struggles to work with dehqon farmers because they see themselves as exceptional and not bound by irrigation policies established. She tells all her employees not to call them rais but instead use the polite term for older brother ( $a k a)$ or older sister ( $a p a$ ) so they can begin discussions on more equal footing. Affirming the rationale behind this practice, the engineer of one WUA explained that a belief in the primacy of dehqon farmers over other cultivators and community members has manifest in a social hierarchy.

"People do not know enough. In their minds dehqon farmers are above everyone. People don't know the law, if they did, they would see that whatever the difference between dehqon farms and kitchen gardens, they have the same rights"... ."There is no law that says dehqon farmers have a higher status. They should have the same position [as kitchen gardens]. [But] 
the dehqon farmers think this way and the households with kitchen gardens also think this way, that they are lower and the dehqon farmers are higher."

His claim is evidenced by households' perceptions of local power relations, as almost all the villagers I spoke with felt that the voices of dehqon farmers receive greater respect. "Here," one woman explained, "the voices of the household mean nothing. They [dehqon farmers] grow cotton and watermelons. They are rich, so their rights are given more importance than ours." The role of wealth, be it in the form of cash or land, in informing the social status of dehqon farmers and in relation, households, was frequently referenced by interviewees. For example, another woman commented,

“you can't say anything about it [inequity of water access]. Right now, is the era of the wealthy, if you have money, you can speak ... . We came here because we have five children and there was not enough room in the house of my husband's parents. But here, there is no water, no school, no doctor, no one asks after your condition, no one asks how you are doing. Here, there is just the flies that bite at our faces."

As discussed earlier in regard to water access, many households rejected the notion that the secondary concern given their plots by water management officials was natural or inherent. Challenging what he feels is the dominant approach to assigning the two plots value, a male householder stated,

"dehqon farms have a higher position in our area but kitchen gardens should be higher, because on these ten sotiq [one sotiq is equal to 0.01 hectares] you can grow everything. On the dehqon farms it is just onions and cotton. On the kitchen garden everything is grown, vegetables, fruit trees-these are essential to life."

Acknowledging the uneven power dynamics at work, one WUA staff explained that "I provide kitchen gardens with irrigation assistance first, because dehqon farms have money, they have other opportunities. They can easily access water themselves. I give water to the kitchen gardens first but in general, the claims of dehqon farms receive priority." While individuals like him may choose to actively counter the privilege afforded to dehqon farmers, because WUAs formally divide the community into members and non-members based on the possession of farmland, as a whole, these institutions discursively reaffirm farmers' prestige.

Due to a perceived connection between women and kitchen garden cultivation, by only extending membership to dehqon farms, WUAs also inadvertently signal that women's work in kitchen gardens is of less significance, reinforcing patriarchal gender norms. In response to widespread male outmigration, women are also taking on significant responsibility for farm plot irrigation. While most women described farm-level irrigation as a burden rather than an opportunity because of the physical toll and time it extracts, they nevertheless saw their ability to work in this area as a necessity. However, historically a male-dominated activity, many women felt they lacked vital technical knowledge of water system operations and administration. As just over 13 percent of dehqon farm managers are women and thus may formally participate in the WUA, the vast majority of rural women are left without the opportunity to formally join in the shared learning and networking that is thought to follow from active engagement with community-based institutions [13]. In effect, knowledge of the irrigation system and by extension, the ability to change when and where water flows thus becomes concentrated in an elite, male segment of the rural communities, reinforcing a social hierarchy that marginalizes poor households and women's control of natural resources. This outcome is diametrically opposed to the inclusive decision-making that WUAs were intended to advance.

\section{Conclusions}

Donors have committed to funding 91 percent of the budget for the Water Sector Reforms Program of the Republic of Tajikistan for 2016-2025, a figure which affords them significant sway over the 
way it unfolds [61]. WUAs, as one component of this program, are rewriting the management of water at the local level. Presumed to bring about an increase in water access, crop yields and food availability through activities that are grounded in the self-expressed needs of community members, I question the likelihood of this outcome. Highlighted by scholars globally, the way that the community is understood by development organizations is often problematic, tending towards a vision of a socially and economically homogenous group. Informing project design, this blurry image of rural life neglects underlying divergence in resource use and livelihood strategies, resulting in exclusionary outcomes that contradict the initiatives' inclusive intentions. As non-members, households that only possess kitchen gardens are quite literally without a "seat at the table" when decisions are made by the WUA. This leaves their ability to formally access water and attendant chance of a successful harvest, tenuous and dependent on appeals to farmers within their community. The logical basis for community-based natural resource management may suggest that this is not a significant concern, as mutual understanding and shared interests within the community will assure that resource distribution satisfies the needs of all users. This article challenges this notion, highlighting how stratification within a community can inform the distribution of power within an organization, with significant bearing on an individual's ability to access and use water as required by their livelihood strategies.

Control of local irrigation systems has been vested in dehqon farmers via their exclusive ability to become members of the WUA. As such, association practices, including the scheduling of water delivery, are likely to become more closely attuned to the needs of farm plots and specific crops like cotton. The water requirements of kitchen gardens differ considerably from those of dehqon farms, meaning the emergence or aggravation of challenges in accessing adequate water for households is probable. Yet the ability of households to rely on WUA support in coping with these shortages is similarly deterred by their status as non-members. In this way, WUAs have the potential to widen cleavages in society, as individuals with farmland gain increased command of community affairs, while those without farmland are subject to increased marginalization. Instead of subverting the existing social order to increase the equity of water delivery and accessibility and support the cultivation of food crops among food insecure households, WUAs then reinforce a social order that favors elite male farmers and valorizes the cultivation of commodities like cotton, rather than valuing the potential of kitchen gardens to feed communities.

Ruth Meinzen-Dick writes that in the search for panaceas in water governance, policy narratives, even those based on research,

"promote a particular institutional approach has too often ignored the evidence on shortcomings of the proposed approach and the conditions under which that type of institution is likely to function poorly or well. Donor agencies and policy makers are attracted to the simplicity of an apparently successful model that offers a recipe for application elsewhere. Something that may have functioned well in one part of the Philippines, Mexico or Chile is promoted in sweeping reforms applied to large areas that have very different resource systems, governance systems, resource units and users." [25] (p. 15204)

To this list, I would add very different "strategies for ensuring adequate food and nutrition." Taking seriously the ways that households access food, must be an essential part of analyses of water governance structures and the policy prescriptions that lead from them, lest reduced food security become a "shortcoming" of future interventions in irrigation management.

While WUAs are based in a development ideal that has been the subject of decades of critique, they nevertheless remain a popular intervention among bi-lateral and multi-lateral agencies. Tajikistan is not the only and not likely the last country that will see these associations presented as an opportunity to overcome costly and ineffectual state-centric water governance, rural water shortages, poor harvests or a lack of civil engagement. This reality demands continued engagement with past scholarship, refining and advancing these arguments to excavate the way that current interventions produce 
inequality in decision-making and resources access. Analyses should not, however, end here but follow through to the consequences of such inequality, particularly with regard to food security, bridging literatures to develop a fuller understanding of how changes in the politics of water governance reverberate in all aspects of community life.

Funding: Funding for fieldwork was provided by the American Councils Title VIII Research Scholar Program as well as Syracuse University Geography Department Graduate Research Funding.

Acknowledgments: I give my deepest thanks to all those who have taken the time to share their thoughts and goodwill with me in Tajikistan, in particular, Shifo Sharifzoda and Husnoro Saidova. I would also like to thank Tom Perreault, Natalie Koch and Anne Bellows for their support and feedback.

Conflicts of Interest: The author declares no conflict of interest.

\section{Abbreviations}

FtF Feed the Future, U.S. Government's global hunger and food security initiative

TAWA USAID Tajikistan Agriculture and Water Activity

TJS Tajikistani Somoni, national currency

USAID United States Agency for International Development

USSR United Soviet Socialist Republics

WUA Water User Association

\section{References}

1. Agarwal, B. Re-sounding the alert-Gender, resources and community action. World Dev. 1997, 25, 1373-1380. [CrossRef]

2. Agarwal, B. Participatory exclusions, community forestry, and gender: An analysis for South Asia and a conceptual framework. World Dev. 2001, 29, 1623-1648. [CrossRef]

3. Ahluwalia, M. Representing Communities: The Case of a Community-Based Watershed Management Project in Rajas than, India. IDS Bull. 1997, 28, 23-35. [CrossRef]

4. Bruns, B. Community priorities for water rights: Some conjectures on assumptions, principles and programmes. In Community-Based Water Law and Water Resource Management Reform in Developing Countries; van Koppen, B., Giordano, M., Butterworth, J., Eds.; CABI: Wallingord, UK, 2007; pp. 28-45, ISBN 978-1-84593-326-5.

5. Cleaver, F. Paradoxes of participation: Questioning participatory approaches to development. J. Int. Dev. 1999, 11, 597-612. [CrossRef]

6. Cornwall, A. Whose voices? Whose choices? Reflections on gender and participatory development. World Dev. 2003, 31, 1325-1342. [CrossRef]

7. Goldin, J.A. The Participatory Paradigm: Anathema, Praise and Confusion. In Contemporary Water Governance in the Global South: Scarcity, Marketization and Participation; Harris, L.M., Goldin, J.A., Sneddon, C., Eds.; Routledge: London, UK, 2013; pp. 179-184, ISBN 978-0-415-65799-0.

8. Hildyard, N.; Hegde, P.; Wolvekamp, P.; Reddy, S.; Cooke, B.; Kothari, U. Pluralism, Participation and Power: Joint Forest Management in India. In Participation: The new Tyranny? 4th ed.; Cooke, B., Kothari, U., Eds.; Zed Books: London, UK, 2001; pp. 1-15, ISBN 9781856497947.

9. Mehta, L.; Leach, M.; Scoones, I. Editorial: Environmental governance in an uncertain world. IDS Bull. 2001, 32, 1-9. [CrossRef]

10. Meinzen-Dick, R.; Zwarteveen, M. Gendered participation in water management: Issues and illustrations from water users 'associations in South Asia. Agric. Hum. Values 1998, 15, 337-345. [CrossRef]

11. Budds, J.; Sultana, F. Exploring political ecologies of water and development. Environ. Plan. D 2013, 31, 275-279. [CrossRef]

12. Van Houweling, E.; Hall, R.; Carzolio, M.; Vance, E. 'My Neighbour Drinks Clean Water, While I Continue to Suffer': An Analysis of the Intra-Community Impacts of a Rural Water Supply Project in Mozambique. J. Dev. Stud. 2016, 53, 1147-1162. [CrossRef]

13. Mukhamedova, N.; Wegerich, K. Integration of villages into WUAS-The rising challenge for local Water management in Uzbekistan. Int. J. Water Gov. 2014, 2, 153-179. [CrossRef] 
14. Guijt, I.; Kaul Shah, M. Waking Up to Power, Conflict and Process. In The Myth of Community: Gender Issues in Participatory Development; Guijt, I., Kaul Shah, M., Eds.; Intermediate Technology Publications: London, UK, 1998; pp. 1-23, ISBN 978-1853394218.

15. Reed, M.S. Stakeholder participation for environmental management: A literature review. Biol. Conserv. 2008, 141, 2417-2431. [CrossRef]

16. Agrawal, A.; Gibson, C. Enchantment and Disenchantment: The Role of Community in Natural Resource Conservation. World Dev. 1999, 27, 629-649. [CrossRef]

17. White, S. Depoliticizing development: The uses and abuses of participation. Dev. Pract. 1996, 6, 6-15. [CrossRef]

18. The World Bank. The World Bank Participation Sourcebook; The International Bank for Reconstruction and Development/The World Bank: Washington, DC, USA, 1996.

19. Berkes, F.; Feeny, D.; McCay, B.J.; Acheson, J.M. The Benefits of the Commons. Nature 1989, 340, 91-93. [CrossRef]

20. Mohan, G.; Stokke, K. Participatory development and empowerment: The dangers of localism. Third World Q. 2000, 21, 247-268. [CrossRef]

21. Nelson, N.; Wright, S. Power and Participatory Development: Theory and Practice; ITDG Publishing: London, UK, 1995; ISBN 9781853392412.

22. Sultana, F. Community and participation in water resources management: Gendering and naturing development debates from Bangladesh. Trans. Inst. Br. Geogr. 2009, 34, 346-363. [CrossRef]

23. Bakker, K. The "commons" versus the "commodity": Alter-globalization, anti-privatization and the human right to water in the global south. Antipode 2007, 39, 430-455. [CrossRef]

24. Meinzen-Dick, R.; Reidinger, R. Participation in Irrigation. In Proceedings of the Social Development Papers the World Bank, Washington, DC, USA, 3 February 1995.

25. Meinzen-Dick, R. Beyond Panaceas in Water Institutions. Proc. Natl. Acad. Sci. USA 2007, 104, 15200-15205. [CrossRef] [PubMed]

26. Hunt, R. Appropriate Social Organization? Water User Associations in Bureaucratic Canal Irrigation Systems. Hum. Organ. 1989, 48, 79-90. [CrossRef]

27. IWMI (International Water Management Institute). Water User's Associations in the Context of Small-Holder Agriculture: A Systematic Review of IFAD Funded Water Users Association in Asia; International Water Management Institute: Battaramulla, Sri Lanka, 2011.

28. Feed the Future. Growing More with Less: Feed the Future and Water. Feed the Future: The US Government's Hunger and Food Security Initiative. 2013. Available online: https:/ / reliefweb.int/report/senegal/growingmore-less-feed-future-and-water (accessed on 30 October 2018).

29. Yu, H. Can Water Users' Associations Improve Water Governance in China? A Tale of Two Villages in the Shiyang River Basin. Water Int. 2016, 41, 966-981. [CrossRef]

30. Cooke, B.; Kothari, U. The Case for Participation as Tyranny. In Participation: The New Tyranny? 4th ed.; Cooke, B., Kothari, U., Eds.; Zed Books: London, UK, 2001; pp. 1-15, ISBN 9781856497947.

31. Platteau, J.P. Monitoring elite capture in Community-Driven development. Dev. Chang. 2004, 35, $223-246$. [CrossRef]

32. Mustafa, D.; Altz-Stamm, A.; Mapstone, L. Water User Associations and the Politics of Water in Jordan. World Dev. 2016, 79, 164-176. [CrossRef]

33. Family Farming Program Staff. USAID Family Farming Program for Tajikistan-Annual Report Year 4, October 2013-September 2014; Economic Growth Office: Berkeley, CA, USA, 2014.

34. Salman, S. The Legal Framework for Water Users' Associations: A Comparative Study; World Bank: Washington, DC, USA, 1992.

35. Zwarteveen, M. Linking Women to the Main Canal; Sustainable Agriculture and Rural Livelihoods Programme, Gatekeeper Series No. 54; International Institute for Environment and Development: London, UK, 1995.

36. Subramanian, A.; Jagannathan, N.V.; Meinzen-Dick, R. User organizations for sustainable water services. World Bank Tech. Pap. 1997, 354. [CrossRef]

37. Sehring, J. The Politics of Irrigation Reform in Tajikistan. Discussion Papers/Zentrum für internationale Entwicklungs-und Umweltforschung, 2006. No. 29. Available online: http://hdl.handle.net/10419/21925 (accessed on 30 October 2018). 
38. Qiao, G.; Zhao, L.; Klein, K.K. Water User Associations in Inner Mongolia: Factors That Influence Farmers to Join. Agric. Water Manag. 2009, 96, 822-830. [CrossRef]

39. Spoor, M. 'White Gold' Versus 'Food Self-Sufficiency' in Former Soviet Central Asia. In Agricultural Markets Beyond Liberalization; van Tildburg, A., Moll, H., Kuyvenhoven, A., Eds.; Springer: New York, NY, USA, 2000; pp. 57-76, ISBN 978-1461370406.

40. Peterson, M. US to USSR: American experts, irrigation, and cotton in soviet central asia, 1929-1932. Environ. History 2016, 21, 442-466. [CrossRef]

41. Horinkova, V.; Abdullaev, I. Institutional Aspects of Water Management in Central Asia Water Users Associations. Water Int. 2003, 28, 237-245. [CrossRef]

42. Rowe, W. 'Kitchen gardens' in Tajikistan: The Economic and Cultural Importance of Small-Scale Private Property in a Post-Soviet Society. Hum. Ecol. 2009, 37, 691-703. [CrossRef]

43. Patnaik, A. Agriculture and Rural Out-Migration in Central Asia, 1960-1991. Eur.-Asia Stud. 1995, 47, 147-169. [CrossRef] [PubMed]

44. Bayarsaihan, T.; McKinney, D. Past Experiences and Future Challenges: Cooperation in Shared Water Resources in Central Asia; Asian Development Bank: Mandaluyong, Philippines, 2004.

45. Hasanzoda, G. Nishondihandahoi Genderi Oid ba Fa'oliyati Istihsolii Xojagihoi Dehqoni dar Solhoi 2009-2014 [Gender Indices in Dehkon Farm Activity Production]; Agency on Statistics under President of the Republic of Tajikistan: Dushanbe, Tajikistan, 2015.

46. Buisson, M.-C.; MacDonald, K.; Saikia, P.; Balasubramanya, S.; Aslamy, S.; Horbulyk, T. Impact of Water Users Associations on Water and Land Productivity, Equity and Food Security in Tajikistan. Mid-term Technical Report; International Water Management Institute: Colombo, Sri Lanka, 2014.

47. Oblitas, R. Farm Privatization Support Project; Report Number ICRR 12525; ICR Review, Independent Evaluation Group: Washington, DC, USA, 2006.

48. Abdullaev, I.; Rakhmatullaev, S. Transformation of water management in Central Asia: From State-centric, hydraulic mission to socio-political control. Environ. Earth Sci. 2015, 73, 849-861. [CrossRef]

49. USAID. USAID Country Profile, Property Rights and Resource Governance, Tajikistan. 2016. Available online: https://www.land-links.org/wp-content/uploads/2016/09/USAID_Land_Tenure_Tajikistan_ Profile.pdf (accessed on 30 October 2018).

50. The World Bank. Project Appraisal Document on a Proposed Credit in the Amount of SDR 14.8 Million (US \$20 Million Equivalent) to the Republic of Tajikistan for Farm Privatization Support Project. Report No. 19318 TJ. In Document of the World Bank Environmentally and Socially Sustainable Development Azerbaijan, Tajikistan; Uzbekistan and Aral Sea Country Unit, Europe and Central Asia Region; The World Bank: Washington, DC, USA, 1999.

51. Campbell, J.; Karchner, M. Uniting Tajikistan's Farmers to Fix Broken Irrigation Systems, DAI. 2015. Available online: https: / / dai-global-developments.com/articles/uniting-tajikistans-farmers-to-fix-broken-irrigationsystems / (accessed on 30 October 2018).

52. Feed the Future. Tajikistan Modernizes Irrigation Systems at National and Local Levels. Feed the Future News and Events; 2014. Available online: https:/ / www.feedthefuture.gov/article/tajikistan-modernizesirrigation-systems-national-and-local-levels (accessed on 10 March 2019).

53. Feed the Future. In Tajikistan, Water Users Associations Help Diversify Agriculture and Build Communities. Feed the Future News and Events; 2013. Available online: https://www.feedthefuture.gov/article/intajikistan-water-users-associations-help-diversify-agriculture-and-build-communities / (accessed on 30 October 2018).

54. Law of the Republic of Tajikistan on Water Users' Associations; Government of Tajikistan: Dushanbe, Tajikistan, 2006.

55. Meinzen-Dick, R.; Jackson, L.A. Multiple Uses, Multiple Users of Water Resources. In Proceedings of the International Association for the Study of Common Property Meetings, Berkley, CA, USA, 5-8 June 1996.

56. Harris, L. Negotiating Inequalities: Democracy, Gender, and Politics of Difference in Water User Groups of Southeastern Turkey. In Environmentalism in Turkey; Adaman, F., Arsel, M., Eds.; Ashgate Publishing: New York, NY, USA, 2005; pp. 185-200. ISBN 9780754644477.

57. Cleaver, F.; Elson, D. Women and Water Resources: Continued Marginalisation and New Policies; International Institute for Environment and Development Sustainable Agriculture Programme: London, UK, 1995; ISBN 1843800217. 
58. Zwarteveen, M. Men, masculinities and water powers in irrigation. Water Altern. 2008, 1, 111-130.

59. Goldin, J.A. Water policy in South Africa: Trust and knowledge as obstacles to reform. Rev. Radic. Politic. Econ. 2010, 42, 195-212. [CrossRef]

60. Mukhamedova, N.; Wegerich, K. Land Reforms and Feminization of Agricultural Labor in Sughd Province, Tajikistan; International Water Management Institute (IWMI): Colombo, Sri Lanka, 2014. [CrossRef]

61. Government of the Republic of Tajikistan. Water Sector Reforms Programme of the Republic of Tajikistan for 2016-2025. Resolution of the Government of Tajikistan Approved on 30 December 2015; No. 791; Government of the Republic of Tajikistan: Dushanbe, Tajikistan, 2015.

(C) 2019 by the author. Licensee MDPI, Basel, Switzerland. This article is an open access article distributed under the terms and conditions of the Creative Commons Attribution (CC BY) license (http://creativecommons.org/licenses/by/4.0/). 